\title{
The Need for a Subject Classifi- cation to Facilitate Research in Foreign Law
}

Miles O. Price is librarian of the Law School of Columbia University.

THE admirable paper by Professor 1 Frederick C. Hicks in the June College and Research Libraries, on the professional aspects of law librarianship, was what his colleagues have learned to expect from his scholarly pen. However, in his discussion of subject classification for law libraries he has overlooked a most important factor concerning the research type of law library-a factor which persuaded me to yield to the requests of my library committee here at Columbia to install such a classification. This factor is the peculiar requirements of the research worker, whether teacher or graduate student, especially in the field of foreign law.

I thoroughly agree with Professor Hicks that for most law libraries a subject classification would be an expensive nuisance, more likely to confuse and delay than to help. Perhaps a brief explanation of the reasons back of that general feeling among law librarians in opposition to classification would be pertinent here.

Anglo-American law is based upon the English common law as modified by statute, and the common law is what the layman would call unwritten law. In other words, it has grown up as a sort of crys- tallized custom, and its rules are found in no statute books. Of late years statute law has become increasingly important, but the foundation of the rules that govern most of our daily actions is still the common law. To make a too great simplification, the law-common and statutory -is in the last analysis what the appellate courts say it is, and the way a court says what a rule of law is, is by a decision in a concrete case. To avoid the endless confusion and consequent hardship of inconsistent decisions, there has grown up a rule known as stare decisis, which means that a truly decided case is to be regarded as authority in similar cases arising in the future in the same court or in lower courts in the same jurisdiction. For sufficient reason the same court may overrule or modify an earlier decision, by a later one, but it is not often done, especially when real property rights are involved.

The pertinency of all this for this discussion is that the authority which a lawyer seeks is found in the statutes and in the decisions of appellate courts which decide rules of common law and interpret statutes, and not in textbooks. Textbooks in law are not authority, but merely more or less elaborate case-finders and indexes to or discussions of the law. To be sure, certain commentaries, as Blackstone and 
Kent, or monographs, as Wigmore on evidence and Williston on contracts, have achieved high prestige as secondary authority, but no judge is bound to respect or follow them.

\section{Preponderance of Unclassifiable Material}

The result is that a conventional working law library, not of the research type, is composed of a great many law reports, some statutes, and several groups of guides to these reports and statutes; such as digests, tables of cases, citation books, encyclopedias, legal periodicals, and textbooks or treatises. Of these, only the last two, and for practical purposes in AngloAmerican law, only the last, are susceptible to subject classification. The others are grouped in a conventional fashion which, as Professor Hicks has pointed out elsewhere, is really a classification dictated by the nature of large sets, but not a subject classification as in history, chemistry, or geology.

Session laws are bound up in the order of their approval by the president or governor. Occasional revisions and consolidations of statutes in force are classified within themselves, but are of course shelved with other statutes of that jurisdiction. The law reports in each bound and consecutively numbered volume of reports are arranged chronologically by the date of each decision. There are probably three million decisions, and they pour forth from the courts at the rate of 30,000 a year in America alone. They are made accessible by digests, which are arranged by subject classifications familiar to all lawyers; by tables of cases, all of which are shelved near the reports themselves; and by treatises, which cite cases in support of their own views.

The minimum library of 10,000 vol- umes required of member schools of the Association of American Law Schools dismisses classifiable material with four words in its fifth specification: "(5). Leading up-to-date publications in the way of general digests, encyclopedias, and treatises of accepted worth." A rather idealistic catalog for a law library of 15,000 volumes drawn up for my course in law library administration three years ago by Raymond Lindquist, librarian of the New York Law Institute (a library of 125,000 volumes), contained only $78 \mathrm{I}$ volumes of legal periodicals and 1242 of textbooks, the remaining 13,000 volumes being strictly nonclassifiable. And the number both of legal periodicals and of texts as given by Mr. Lindquist was considerably higher than would be found in the ordinary working library of 15,000 volumes. Eliminating legal periodicals, which are for the most part of a general nature in America and not classifiable by subject, we have about one-twelfth of the library classifiable at the most. This is a high percentage for law libraries, and the smaller the library, the lower the percentage of texts.

Of the approximately 631 American law libraries listed in the Standard Legal Directory for I939, I6I contained less than 5000 volumes; 146 , between 5000 and 10,000 volumes; I $5 \mathrm{I}$, between 10,000 and 20,000 volumes; 94 , between 20,000 and 50,000 volumes; 39 , between 50,000 and 75,000 volumes; 28 , between 75,000 and I 50,000 volumes; and I 2, over I 50,000 volumes. (Of the large libraries, several were state libraries, containing more nonlegal material, such as history or economics, than is usual in law libraries.) That is, 75 per cent of the organized law libraries listed contained less than 20,000 volumes, and by the same token, probably, 
only a negligible amount of material classifiable by subject. Because of the large proportion of long sets, a law library of 20,000 volumes is not considered large, and is likely to be a "one-man" library. Also, because of the relatively few texts, its catalog, if any, is probably rudimentary. I know of one bar association library of 70,000 volumes, and a good one, which has no catalog, but only a short-form author list.

All of this material, except possibly texts, is kept on open shelves for the lawyers' ready consultation, which is another argument against classification. Even when the library increases in size, the material is probably for the most part sets of continuations, such as added reports and statutes, or printed appeal papers, reports of attorneys-general and bar associations-all similarly unclassifiable by subject.

Normally, the lawyer is looking for a case, and other material is incidental to that search. That is true even of good texts, which after all embody only the opinion of unofficial persons as to what the law is. The lawyer will sometimes cite texts as make-weights, but what he wants is a case in point. Therefore, he is searching for definite citations, as Professor Hicks points out, and does not care where he finds them, and under the circumstances a subject classification is a nuisance. I have so told many librarians of small collections who were interested in subject classification, and advised them not to attempt it.

\section{Problems of Closed Stacks and Research Workers}

However, when a substantial part of the library outgrows the open shelves, and when research workers are to be con- sidered, that situation loses some of its effect. Research workers are interested in citations in other books, it is true. More important to this discussion, however, is that they are pushing back the boundaries of knowledge and are soon beyond the point where they depend exclusively or mainly on somebody else's citations. They are themselves giving the citations.

Professor Hicks is quite correct in stating that legal literature is fully covered by printed indexes which are probably far more complete and up to date than in any other field. That is, he is correct as to Anglo-American laws, statutes, reports, and periodicals. These are covered by complete, speedy, and relatively inexpensive index services beyond those dreamed of in other fields. However, these do not cover foreign law well, and treatises not at all. For example, in the Columbia University Law Library there are over 25,000 volumes of treatises in AngloAmerican law alone, not counting international law and foreign relations. These are not on open shelves and are available as open-shelf books only to graduate students, faculty, and editors of the Law Review. However, real accessibility is gained only through our catalog, which is a considerable distance from the stacks.

We librarians must admit that our patrons hate to use a catalog, and the larger our collection and the more the cards, the more they hate it. It is an invaluable tool, but a nuisance to the reader, nevertheless. It is necessary to supplement a classification, too, of course, because authors do not write books with a subject classification in mind. However, this is true of a classification covering any subject, as chemistry, engineering, or economics, all of which have been successfully 
classified for years. And in no science is it truer than in law, that authors are writing "more and more about less and less." Even in Anglo-American law, for every general work on a large topic, such as Cook or Fletcher on corporations, we have a dozen or more like Berle, Studies in Corporation Finance; Davis, Essays in the Early History of American Corporations; Doris, Corporate Meetings; Latty, Subsidiaries and Affiliated Corporations; Spellman, Corporate Directors; Tracy, Corporate Foreclosures; and the like. Certainly there is little overlapping here.

The librarian in chemistry or history or economics would be horrified at the sight of 25,000 unclassified treatises, accessible only through even the best possible catalog. Since the success of our foreign law classification I am beginning to feel more and more that way myself. However, we are approaching the matter carefully, because of the practical unanimity of law librarians' opposition to subject classification, and of the cogency of the arguments marshalled by Professor Hicks. But there is authority on the other side, too. The late G. E. Wire, longtime librarian of the Worcester County (Mass.) Law Library, and the chief protagonist of the subject classification of law books, employed such a classification successfully for years, even with open shelves and in a medium-sized library. The frequent requests from law librarians for a subject classification of Anglo-American law books indicate that the matter is by no means permanently settled.

\section{Subject Classification in Foreign Law}

When it comes to foreign law we at Columbia are in no doubt at all as to the value, if not necessity, of a subject classification for treatises. We have one and it works. Perhaps the makeup of the library committee which persuaded me to consent to a subject classification will help to explain my point: its chairman is professor of Roman law; another member is professor of comparative law, doing most of his work with foreign legal systems; and the third is professor of legal history. This committee felt that while, as far as they knew, the needs of the worker in Anglo-American law might be sufficiently taken care of by the conventional alphabetical arrangement of treatises, they were so hampered in their research in foreign law that a subject classification was worth its great cost.

There are several reasons why a subject classification in foreign law in this country stands on a different footing from that of Anglo-American law. One is the much higher standing of the commentary and treatise, as opposed to the law report, in the civil law which is the basis of most foreign law. In few civil law countries does the law report have anything near the prestige it enjoys in this country or England. In some constitutions it is even provided that no court shall be bound by a prior decision. A treatise or commentary by a recognized scholar in a given field of law may have more authority than that of a line of decisions, and usually the courts will not have the temerity to go counter to such a commentary. Therefore, the treatise is much more important in foreign law than in Anglo-American law. It may be stated here also that the legal periodical in civil law countries is considerably more likely to be devoted to a relatively small area of the law than in this country, and therefore classifiable by subject.

Probably the impelling reason in our case, however, for adopting a subject class- 
ification was the fact that practically the only users of our foreign law collection are research workers-graduate students and faculty - and that the entire collection is in the stacks, at a considerable distance from the catalog. There was thus a vitally different setup from that existing in Anglo-American law.

\section{Results of Subject Classification}

After three years of studying the pros and cons, I was convinced that my library committee was justified in its position, and the re-classification of our foreign law collection was begun. The classification, except for some minor matters of form, mnemonic features, etc., was devised by A. A. Schiller, chairman of the library committee, professor of Roman law, and expert on foreign legal systems. We feel that the results have fully vindicated us. Research workers now can go to the stacks and find most of the material they need in a closely and logically classified group, instead of having to wander through thousands of alphabetically arranged works. This saves time and brings together in one place the actual material to be worked with-which is much more satisfactory than even the best subject catalog (and at Columbia we have one of the best).

Where formerly the research worker in French law, for example, had to paw through 2500 alphabetically arranged treatises, after laboriously copying call numbers at the public catalog, he can now go to the stacks, either after getting the call number of his topic from the catalog, or after consulting the classification scheme posted in many places in the stacks, and there find his material together. To be sure, he will, as in other sciences, have to check with cross-references in the catalog to be certain that he has missed nothing, but that is a much shorter process than depending wholly upon the catalog.

In our library considerable research is done in the fields of family law and industrial property (patents, trade-marks, copyright, etc.). The law of persons (including family) is embraced in numbers 329-99 of our classification. Marriage, numbers $370-99$, has 170 titles in French law alone. Industrial property is 670-90. When a comparative study is being made of that subject, the worker does not have to spend hours at the cata$\log$, or searching through 2500 French, 2000 German, 600 Dutch, and 400 Italian titles of treatises to find his material. Instead, he quickly finds nearly all of it in our 97 French, I20 German, 20 Italian, and 7 Dutch titles of treatises and special periodicals, in their proper places on the shelves.

Professor Hicks has pointed out the disadvantages of a subject classification in the field of law, and I agree with him. I firmly believe, however, that in the large research library, particularly where there is a very large group of treatises, and more particularly where there is a large collection of foreign law used by research workers rather than by the bulk of the library patrons, the subject classification is justified and provision should be made for it. 